\title{
Registration Authority
}

National Cancer Institute

\section{Source}

National Cancer Institute. Registration Authority. NCI Thesaurus. Code C74932.

An org anization authorized to register a registry item. 